\title{
Etnobotani Tumbuhan Obat Suku Melayu Desa Durian Sebatang Kecamatan Seponti Kabupaten Kayong Utara
}

\author{
Firgian Dine Wulandara ${ }^{1}, \operatorname{Rafdinal}^{1}, \operatorname{Riza}_{\text {Linda }}{ }^{1}$ \\ ${ }^{1}$ ProgramStudi Biologi, Fakultas MIPA, Universitas Tanjungpura, Jl. Prof. Dr. H. Hadari Nawawi, Pontianak, \\ Email:firgian28@gmail.com
}

\begin{abstract}
This research was conducted with the aim to know the types of medicinal plants, parts of plants used as medicines and methods of processing and the use of plants as a traditional medicine. The research was conducted four months, starting from September to December 2017. The research was conducted in Durian Sebatang Village, Seponti Sub-District, North Kayong District. The research method using Purposive Sampling, with selected respondents as many as 8 people, belong to two categories namely 2 people shaman giving birth and 6 people herbalist. The design of this research is observation, then conducted semi-structured interviews and filling questionnaires by respondents. The results showed that there are 43 families and 93 species of plants that have potential as drugs. The highest percentage of families is Zingiberaceae $(9,7 \%)$ and Euphorbiaceae $(9,7 \%)$. Part of a widely used plant is the leaves $(48 \%)$, while the way of processing and the use of medicinal plants is in boiled (48\%) and drunk (53\%). Taking medicinal plants is mostly done in the forest $(36 \%)$.
\end{abstract}

Keywords: Durian Sebatang Village, Ethnobotany, Malay Tribe, Medicinal Plant

\section{PENDAHULUAN}

Kalimantan Barat memiliki sumber daya hutan yang cukup tinggi dengan berbagai jenis tumbuhan obat. Pemanfaatan tumbuhan yang memiliki kandungan senyawa aktif sebagai bahan baku obat tradisional perlu di jaga dan dilestarikan agar dapat dikembangkan dengan baik sebagai salah satu unsur kebudayaan atau kearifan lokal. Masyarakat Kalimantan barat terdiri dari beberapa Suku, salah satunya adalah Suku Malayu. Suku Melayu merupakan suku terbesar yang terdapat di Kalimantan Barat setelah suku Dayak (Notherfer, 1996). Suku Melayu masih mengadakan upacara adat yang menggunakan berbagai jenis tumbuhan, tujuan dilaksanakannya upacara adat ini yaitu untuk menolak bala agar masyarakat terhindar dari segala bentuk marabahaya (Suryansyah, 2011).

Berdasarkan pemaparan diatas penggunaan tumbuhan sebagai bahan dasar pembuatan obat tradisional telah dilakukan oleh masyarakat di berbagai wilayah di Kalimantan Barat. Beberapa tumbuhan obat yang biasa dimanfaatkan oleh masyarakat suku melayu adalah kembang sepatu sebagai obat demam, cengkodok sebagai obat diare atau sakit perut, sirih sebagai antiseptik, seledri sebagai obat penurun darah tinggi, serai sebagai obat gatal-gatal dan sakit gigi, tempuyung sebagai obat dalam, patah kemudi sebagai obat patah tulang. Pengolahan bagian tumbuhan sebagai obat tradisional ini masih sangat sederhana seperti ditumbuk, direbus, ada pula yang di remas dan langsung dibalurkan ke bagian tubuh yang sakit (Aminah, 2013).

Masyarakat Desa Durian Sebatang sebagian besar bersuku Melayu, yang secara tradisional masih menggunakan tumbuhan yang ada di sekitarnya sebagai bahan obat untuk mengobati berbagai macam penyakit. Namun sebagian besar kawasan hutannya telah dijadikan lahan perkebunan karet, perkebunan kelapa sawit dan ladang berpidah. Hal ini berdampak pada berkurangnya potensi tumbuhan obat yang ada di kawasan tersebut. Berdasarkan pernyataan di atas maka perlu adanya upaya pelestarian tumbuhan yang berpotensi sebagai obat tradisional. Informasi jenis tumbuhan dan pemanfaatannya dalam proses pengobatan oleh masyarakat suku Melayu Desa Durian Sebatang ini masih minim sehingga belum terdokumentasi dengan baik, maka dari itu penelitian ini perlu dilakukan.

\section{BAHAN DAN METODE}

Waktu dan Tempat Penelitian

Penelitian dilakukan pada bulan September hingga

Desember 2017di Desa Durian Sebatang

Kecamatan Seponti Kabupaten Kayong Utara, proses identifikasi tumbuhan obat dan pengolahan data dilakukan di Laboratorium Biologi Fakultas Matematika dan Ilmu Pengetahuan Alam, Universitas Tanjungpura, Pontianak. 
Protobiont (2018) Vol. 7 (3) : $36-46$

Deskripsi Wilayah Penelitian

Lokasi penelitian terletak di Desa Durian Sebatang

Kecamatan Seponti Kabupaten Kayong Utara dengan luas sekitar 28,00 $\mathrm{km}^{2}$ (Gambar 1). Adapun batas-batas wilayah Desa Durian Sebatang sebagai berikut (BPS KKU, 2016):

1. Sebelah Utara berbatasan dengan Kabupaten Kubu Raya
2. Sebelah Selatan berbatasan dengan Kecamatan Simpang Hilir

3. Sebelah Barat berbatasan dengan Desa Sungai Sepeti

4. Sebelah Timur berbatasan dengan Kabupaten Ketapang

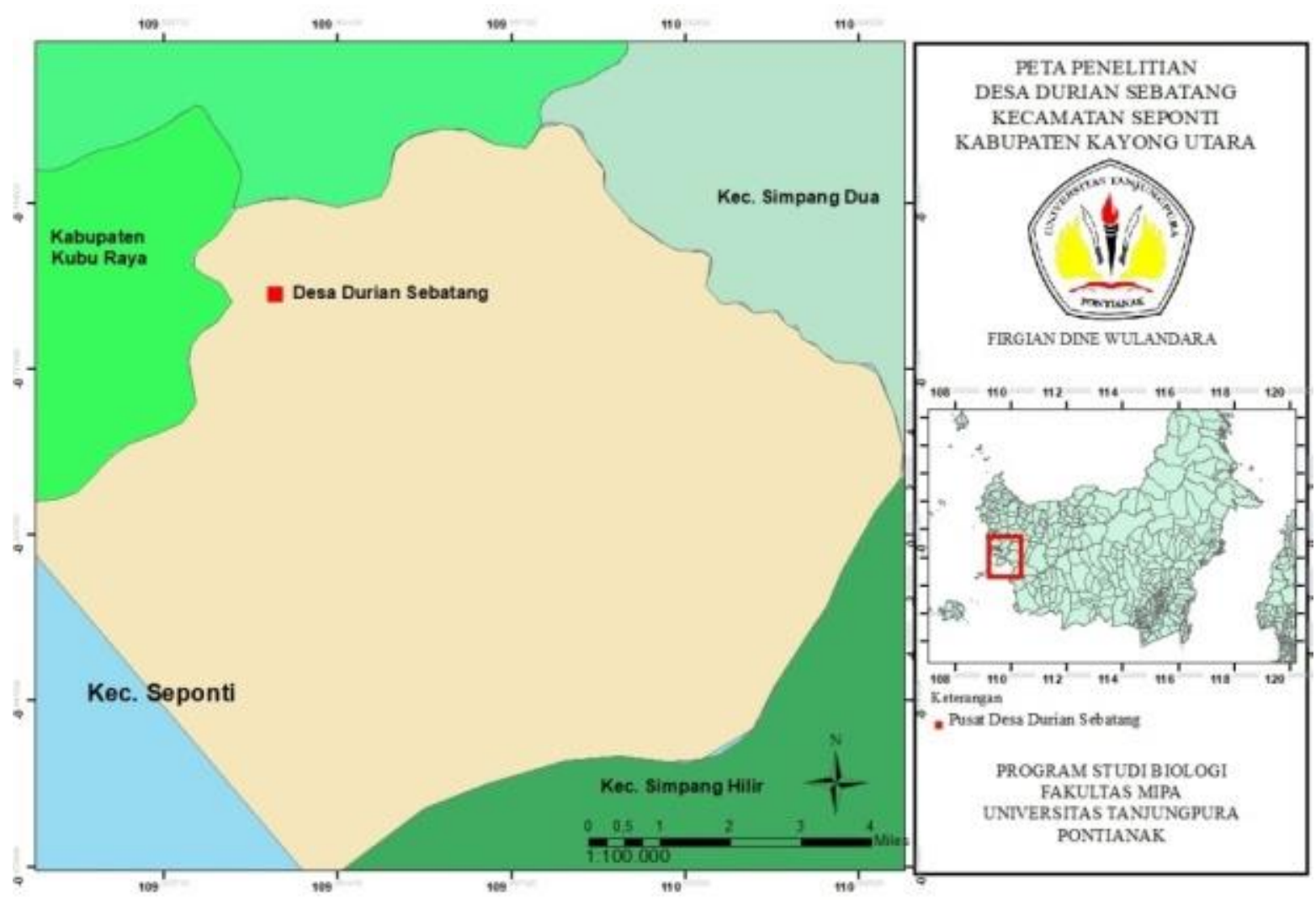

Gambar 1. Lokasi Penelitian

\section{Alat dan Bahan}

Alat dan bahan yang digunakan dalam penelitian ini adalah alat tulis, alat perekam suara, benang, buku identifikasi, gunting, jarum, karton, kertas label, kardus, kertas koran, kamera, kuesioner, sasak bambu $50 \mathrm{~cm}$, pisau/parang, sprayer, tali rapia, selotip bening, plastik, spirtus, dan sampel tumbuhan obat.

\section{Pelaksanaan Penelitian}

Penentuan responden dengan menggunakan metode purposive sampling (Sugiyono, 2014). Responden yang terpilih berjumlah 8 orang tergolong dalam 2 kategori yaitu 2 orang dukun beranak dan 6 orang dukun kampung. Tahapan penelitian ini adalah observasi, wawancara secara semi terstruktur, pengisian kuesioner oleh responden, pengambilan sampel tumbuhan obat, pembuatan herbarium tumbuhan obat dan identifikasi yang dilakukan dengan melihat karakteristik tumbuhan obat berpedoman pada buku determinasi tumbuhan "Flora" (Steenis et al., 2005), buku "Tumbuhan Obat Taman Nasional Gunung Halimun, Jawa Barat, Indonesia" (Harada et al., 2006), buku "Taksonomi Koleksi Tanaman Obat Kebun Tanaman Obat Citeureup" (Badan POM RI, 2008), Database Nature Love you (http://www.natureloveyou.sg/) dan Database Plantamor (http://www.plantamor.com/).Data yang terkumpul kemudian dianalisis secara deskriptif kualitatif.

\section{HASIL DAN PEMBAHASAN}

\section{Hasil}

Berdasarkan hasil penelitian pemanfaatan tumbuhan obat oleh masyarakat Melayu Desa

Durian Sebatang diperoleh 43 famili dan 93 jenis tumbuhan yang berpotensi sebagaiobat tradisional (Tabel 1). Persentase famili terbesar adalah 
Protobiont (2018) Vol. 7 (3) : 36 -46

Zingiberaceae dan Euphorbiaceae $9,6 \%$ dan persentase jenis terkecil adalah Moraceae sampai Solanaceae 1,1\% (Tabel 2). Cara pengolahan dan penggunaan tumbuhan obat oleh masyarakat Desa Durian Sebatang tergantung dari jenis tumbuhan

Tabel 1. Famili dan Jenis Tumbuhan Obat yang digunakan oleh Masyarakat Suku Malayu Desa Durian Sebatang Kabupaten Kayong Utara

\begin{tabular}{|c|c|c|c|c|c|c|}
\hline No. & Famili & $\begin{array}{c}\text { Nama } \\
\text { Daerah }\end{array}$ & Nama Spesies & $\begin{array}{c}\text { Bagian } \\
\text { Tumbuhan }\end{array}$ & $\begin{array}{c}\text { Cara } \\
\text { Pengolahan/ } \\
\text { Penggunaan }\end{array}$ & Kegunaan \\
\hline \multirow[t]{4}{*}{1} & Acanthaceae & Sambiloto & $\begin{array}{l}\text { Andrographis } \\
\text { paniculata (Burm. F.) } \\
\text { Wall. }\end{array}$ & $\begin{array}{l}\text { Batang dan } \\
\text { daun }\end{array}$ & $\begin{array}{l}\text { Direbus/ } \\
\text { Diminum }\end{array}$ & $\begin{array}{l}\text { Asma, obat dalam, demam, } \\
\text { menetralkan racun, kencing batu }\end{array}$ \\
\hline & & Keji beling & $\begin{array}{l}\text { Strobilanthes crispa } \\
\text { BI. }\end{array}$ & Daun & $\begin{array}{c}\text { Ditumbuk/ } \\
\text { Ditempelkan }\end{array}$ & Memar, sakit kepala \\
\hline & & Gandarusa & $\begin{array}{l}\text { Justicia gendarussa } \\
\text { Burm. }\end{array}$ & Daun & $\begin{array}{l}\text { Ditumbuk/ } \\
\text { Ditempelkan }\end{array}$ & Rematik, sakit persendian \\
\hline & & & & Daun & $\begin{array}{l}\text { Direbus/ } \\
\text { Diminum }\end{array}$ & Penurun panas \\
\hline \multirow[t]{2}{*}{2} & Amaranthaceae & Bayam & $\begin{array}{l}\text { Amaranthus } \\
\text { retroflexus L. }\end{array}$ & Daun & $\begin{array}{c}\text { Ditumbuk/ } \\
\text { Ditempelkan }\end{array}$ & Demam \\
\hline & & & & Daun & $\begin{array}{l}\text { Direbus/ } \\
\text { Dimakan }\end{array}$ & Tambah darah \\
\hline 3 & Annonaceae & Sirsak & Annona muricata $\mathrm{L}$. & Daun & $\begin{array}{l}\text { Direbus/ } \\
\text { Diminum }\end{array}$ & Sakit pinggang, kanker, darah tinggi \\
\hline \multirow[t]{3}{*}{4} & Apiaceae & Daun sop & Apium graveolens $\mathrm{L}$. & Daun & $\begin{array}{l}\text { Direbus/ } \\
\text { Dimakan }\end{array}$ & Darah tinggi, asam urat \\
\hline & & Pegage & Centella asiatica $\mathrm{L}$. & Daun & $\begin{array}{l}\text { Direbus/ } \\
\text { Diminum }\end{array}$ & Rematik \\
\hline & & & & Daun & $\begin{array}{l}\text { Direbus/ } \\
\text { Diminum }\end{array}$ & $\begin{array}{l}\text { Demam,muntah darah, keracunan, } \\
\text { batu ginjal }\end{array}$ \\
\hline \multirow[t]{2}{*}{5} & Apocynaceae & Pelaik & Alstonia scholaris $\mathrm{L}$. & $\begin{array}{l}\text { Getah pada } \\
\text { batang }\end{array}$ & $\begin{array}{l}\text { Dipotong/ } \\
\text { Dioles }\end{array}$ & Sakit gigi, obat koreng \\
\hline & & Tapak dara & $\begin{array}{l}\text { Catharanthus roseus } \\
\text { (L.) G. Don }\end{array}$ & Daun & $\begin{array}{l}\text { Direbus/ } \\
\text { Diminum }\end{array}$ & Demam, darah tinggi, sembelit \\
\hline 6 & Araceae & Jeringau & Acorus calamus $\mathrm{L}$. & Rimpang & $\begin{array}{l}\text { Ditumbuk dan } \\
\text { direbus/ } \\
\text { Diminum }\end{array}$ & Sakit perut, nifas \\
\hline \multirow[t]{4}{*}{7} & Arecaceae & Kelapa & Cocos nucifera $\mathrm{L}$. & Akar & $\begin{array}{l}\text { Ditumbuk/ } \\
\text { Diminum }\end{array}$ & Sakit tualng dan persendian \\
\hline & & & & Air buah & $\begin{array}{l}\text { Dipotong/ } \\
\text { Diminum }\end{array}$ & Demam, cacar air, keracunan \\
\hline & & Pinang & Areca cathecu L. & Buah & $\begin{array}{l}\text { Dipotong/ } \\
\text { Ditempelkan }\end{array}$ & Mengeringkan tali pusat bayi \\
\hline & & & & Buah & $\begin{array}{l}\text { Ditumbuk/ } \\
\text { Diminum }\end{array}$ & Menjaga daya tahan tubuh \\
\hline \multirow[t]{4}{*}{8} & Asteraceae & $\begin{array}{l}\text { Patah } \\
\text { kemudi }\end{array}$ & $\begin{array}{l}\text { Gynura segetum (L.) } \\
\text { Merr. }\end{array}$ & Daun & $\begin{array}{l}\text { Ditumbuk/ } \\
\text { Dibalurkan }\end{array}$ & Patah tulang \\
\hline & & & & Daun & $\begin{array}{l}\text { Direbus/ } \\
\text { Diminum }\end{array}$ & Obat dalam \\
\hline & & Tutup bumi & $\begin{array}{l}\text { Elephantopus scaber } \\
\text { L. }\end{array}$ & Daun & $\begin{array}{l}\text { Ditumbuk dan } \\
\text { direbus/ } \\
\text { Diminum }\end{array}$ & $\begin{array}{l}\text { Diare, demam, keputihan, penurun } \\
\text { panas }\end{array}$ \\
\hline & & Kalimau & $\begin{array}{l}\text { Ageratum conyzoides } \\
\text { L. }\end{array}$ & Daun & $\begin{array}{l}\text { Ditumbuk/ } \\
\text { Ditempelkan }\end{array}$ & $\begin{array}{l}\text { Menghilangkan bengkak, } \\
\text { menghentikan } \\
\text { pendarahan pada luka }\end{array}$ \\
\hline
\end{tabular}

yang akan digunakan sebagai obat dan jenis penyakit yang akan di sembuhkan. Sebagian besar tumbuhan obat diperoleh langsung dari hutan (eksplorasi langsung). 
Protobiont (2018) Vol. 7 (3) : 36 -46

\begin{tabular}{|c|c|c|c|c|c|c|}
\hline No. & Famili & $\begin{array}{c}\text { Nama } \\
\text { Daerah }\end{array}$ & Nama Spesies & $\begin{array}{c}\text { Bagian } \\
\text { Tumbuhan }\end{array}$ & $\begin{array}{c}\text { Cara } \\
\text { Pengolahan/ } \\
\text { Penggunaan } \\
\end{array}$ & Kegunaan \\
\hline & & Beluntas & $\begin{array}{l}\text { Pluchea indica }(\mathrm{L} .) \\
\text { Less. }\end{array}$ & Daun & $\begin{array}{l}\text { Direbus/ } \\
\text { Diminum }\end{array}$ & $\begin{array}{l}\text { Menghilangkan bau badan, penambah } \\
\text { nafsu makan, penurun panas }\end{array}$ \\
\hline & & & & & & Obat dalam, darah tinggi \\
\hline & & Tempuyung & Sonchus arvensis $\mathrm{L}$. & Daun & $\begin{array}{l}\text { Direbus/ } \\
\text { Diminum }\end{array}$ & $\begin{array}{l}\text { Obat ginjal, nifas, demam, patah } \\
\text { tulang, obat dalam }\end{array}$ \\
\hline & & $\begin{array}{l}\text { Sambung } \\
\text { nyawa }\end{array}$ & $\begin{array}{l}\text { Gynura procumbens } \\
\text { L. Merr. }\end{array}$ & Daun & $\begin{array}{l}\text { Direbus/ } \\
\text { Diminum }\end{array}$ & $\begin{array}{l}\text { Penambah nafsu makan, penguat } \\
\text { lambung, melancarkan aliran darah }\end{array}$ \\
\hline & & Kenikir & $\begin{array}{l}\text { Cosmos caudatus } \\
\text { Kunth. }\end{array}$ & Daun & $\begin{array}{l}\text { Direbus/ } \\
\text { Dimakan }\end{array}$ & Menyehatkan sistem syaraf \\
\hline & & & & & & $\begin{array}{l}\text { Antimikroba, mengatasi ketombe } \\
\text { pada rambut }\end{array}$ \\
\hline & & Orang aring & Eclipta alba $\mathrm{L}$. & Daun & $\begin{array}{l}\text { Direbus/ } \\
\text { Diminum }\end{array}$ & \\
\hline & & & & Daun & $\begin{array}{l}\text { Ditumbuk/ } \\
\text { Keramas }\end{array}$ & \\
\hline 9 & Basellaceae & Binahong & $\begin{array}{l}\text { Anredera cordifolia } \\
\text { (Ten.) Steenis. }\end{array}$ & Daun & $\begin{array}{l}\text { Direbus/ } \\
\text { Diminum }\end{array}$ & Melancarkan haid, diabetes, asam urat \\
\hline 10 & Bromeliaceae & Nanas & $\begin{array}{l}\text { Ananas comosus (L.) } \\
\text { Merr. }\end{array}$ & Buah & $\begin{array}{l}\text { Dipotong/ } \\
\text { Dimakan }\end{array}$ & Melancarkan pencernaan, sakit perut \\
\hline 11 & Caricaceae & Betik & Carica pepaya $\mathrm{L}$. & Akar & $\begin{array}{l}\text { Ditumbuk/ } \\
\text { Diminum }\end{array}$ & Nyeri sendi \\
\hline & & & & Daun & $\begin{array}{l}\text { Direbus/ } \\
\text { Dimakan }\end{array}$ & Malaria \\
\hline 12 & Convolvulaceae & Ubi jalar & $\begin{array}{l}\text { Ipomoea batatas }(\mathrm{L} .) \\
\text { Lam. }\end{array}$ & Daun & $\begin{array}{l}\text { Ditumbuk/ } \\
\text { Ditempelkan }\end{array}$ & Bisul \\
\hline & & & & Umbi & $\begin{array}{l}\text { Direbus/ } \\
\text { Dimakan }\end{array}$ & Perut kembung \\
\hline 13 & Crassulaceae & $\begin{array}{l}\text { Sosor } \\
\text { bebek }\end{array}$ & Kalanchoe pinnata & Daun & $\begin{array}{l}\text { Ditumbuk/ } \\
\text { Ditempelkan }\end{array}$ & Penurun panas, luka, dan sakit gigi \\
\hline 14 & Cucurbitaceae & Kundur & Benincasa hispida & Buah & $\begin{array}{l}\text { Diparut/ } \\
\text { Diminum }\end{array}$ & Muntah darah \\
\hline & & Periak & $\begin{array}{l}\text { Momordica charantia } \\
\text { L. }\end{array}$ & Daun & $\begin{array}{c}\text { Diremas/ } \\
\text { Dibalurkan }\end{array}$ & Bisul, demam, cacar air \\
\hline 15 & Cyperaceae & Kerisan & Scleria bancana & Daun & $\begin{array}{l}\text { Ditumbuk/ } \\
\text { Ditempelkan }\end{array}$ & Penutup luka \\
\hline 16 & Dilleniaceae & Simpur & $\begin{array}{l}\text { Dillenia suffruticosa } \\
\text { Griff. Ex Hook }\end{array}$ & Daun & $\begin{array}{l}\text { Direbus/ } \\
\text { Diminum }\end{array}$ & Melancarkan ASI, meriang, pegal linu \\
\hline 17 & Euphorbiaceae & Keribang & Manihot utilissima $\mathrm{L}$. & Umbi & $\begin{array}{l}\text { Diparut dan } \\
\text { diperas/ } \\
\text { Diminum }\end{array}$ & Maag \\
\hline & & & & Umbi & $\begin{array}{l}\text { Diparut dan } \\
\text { diperas/ } \\
\text { Ditempelkan }\end{array}$ & Luka bakar \\
\hline & & Jirak & Jatropha curcas L. & Getah & $\begin{array}{l}\text { Dipotong/ } \\
\text { Dioleskan }\end{array}$ & Sariawan \\
\hline & & Jirak hias & $\begin{array}{l}\text { Jatropha podagrica } \\
\text { Hook. }\end{array}$ & Daun & $\begin{array}{l}\text { Ditumbuk/ } \\
\text { Dibalurkan }\end{array}$ & Demam, penetral racun, memar \\
\hline & & $\begin{array}{l}\text { Patah } \\
\text { tulang }\end{array}$ & $\begin{array}{l}\text { Cissus quadrangularis } \\
\text { L. }\end{array}$ & Daun & $\begin{array}{l}\text { Direbus/ } \\
\text { Diminum }\end{array}$ & Penawar petik ikan \\
\hline & & Meniran & Phylanthus niruri L. & & $\begin{array}{l}\text { Direbus/ } \\
\text { Diminum }\end{array}$ & eluruh air seni \\
\hline
\end{tabular}


Protobiont (2018) Vol. 7 (3) : $36-46$

\begin{tabular}{|c|c|c|c|c|c|c|}
\hline No. & Famili & $\begin{array}{c}\text { Nama } \\
\text { Daerah }\end{array}$ & Nama Spesies & $\begin{array}{c}\text { Bagian } \\
\text { Tumbuhan }\end{array}$ & $\begin{array}{c}\text { Cara } \\
\text { Pengolahan/ } \\
\text { Penggunaan }\end{array}$ & Kegunaan \\
\hline & & $\begin{array}{l}\text { Petikan } \\
\text { kebo }\end{array}$ & Euphorbia hirta L. & $\begin{array}{l}\text { Seluruh } \\
\text { bagian } \\
\text { tumbuhan }\end{array}$ & $\begin{array}{l}\text { Direbus/ } \\
\text { Diminum }\end{array}$ & Peluruh air seni \\
\hline & & $\begin{array}{l}\text { Ekor } \\
\text { kucing }\end{array}$ & Acalypha hispida & Daun & $\begin{array}{l}\text { Ditumbuk/ } \\
\text { Dibalurkan }\end{array}$ & $\begin{array}{l}\text { Memar, radang perut, payudara } \\
\text { bengkak }\end{array}$ \\
\hline & & Keminting & $\begin{array}{l}\text { Aleurites moluccana } \\
\text { (L.) Wild. }\end{array}$ & Daun & $\begin{array}{l}\text { Ditumbuk/ } \\
\text { Ditempelkan }\end{array}$ & Sakit gigi \\
\hline & & $\begin{array}{l}\text { Cangkok } \\
\text { manis }\end{array}$ & $\begin{array}{l}\text { Sauropus androgynus } \\
\text { (L.) Merr. }\end{array}$ & Biji & $\begin{array}{l}\text { Direbus/ } \\
\text { Dimakan }\end{array}$ & Melancarkan ASI, demam, maag \\
\hline \multirow[t]{5}{*}{18} & Fabaceae & Asam jawa & Tamarindus indica $\mathrm{L}$. & $\begin{array}{l}\text { Daun } \\
\text { Daun }\end{array}$ & $\begin{array}{l}\text { Ditumbuk/ } \\
\text { Dibalurkan }\end{array}$ & Nifas, menjaga daya tahan tubuh \\
\hline & & & & Buah & $\begin{array}{l}\text { Direbus/ } \\
\text { Diminum }\end{array}$ & $\begin{array}{l}\text { Angin duduk, demam, batuk } \\
\text { Payudara bengkak }\end{array}$ \\
\hline & & $\begin{array}{l}\text { Kacang } \\
\text { panjang }\end{array}$ & Vigna sinensis Endl. & Daun & $\begin{array}{l}\text { Diremas/ } \\
\text { Dibalurkan }\end{array}$ & Kurap, panu \\
\hline & & Gelinggang & Cassia alata $\mathrm{L}$. & Daun & $\begin{array}{l}\text { Diremas/ } \\
\text { Dibalurkan }\end{array}$ & Cacingan, diabetes \\
\hline & & Kelanding & $\begin{array}{l}\text { Leucaena } \\
\text { leucocephala (Lam.) } \\
\text { de Wit }\end{array}$ & Biji & $\begin{array}{l}\text { Direbus/ } \\
\text { Dimakan }\end{array}$ & \\
\hline 19 & Iridaceae & $\begin{array}{l}\text { Bawang } \\
\text { Mekah }\end{array}$ & Eleutherine americana & Umbi & $\begin{array}{l}\text { Direbus/ } \\
\text { Diminum }\end{array}$ & Darah tinggi, penyakit dalam \\
\hline \multirow[t]{2}{*}{20} & Lamiaceae & $\begin{array}{l}\text { Somet } \\
\text { kucing }\end{array}$ & $\begin{array}{l}\text { Orthosipon stamineus } \\
\text { Benth. }\end{array}$ & Daun & $\begin{array}{l}\text { Direbus/ } \\
\text { Diminum }\end{array}$ & Sakit pinggang, peluruh air seni \\
\hline & & Kemangi & $\begin{array}{l}\text { Ocimum basilium } \\
\text { Linn. }\end{array}$ & Daun & $\begin{array}{l}\text { Direbus/ } \\
\text { Dimakan }\end{array}$ & Menghilangkan bau badan \\
\hline 21 & Lauraceae & Kayu manis & $\begin{array}{l}\text { Cinnamomum } \\
\text { burmannii }(\text { Nees \& } \\
\text { Th. Nees) }\end{array}$ & $\begin{array}{c}\text { Kulit } \\
\text { batang }\end{array}$ & $\begin{array}{l}\text { Ditumbuk/ } \\
\text { Dibalurkan }\end{array}$ & Sakit perut, nyeri pinggang \\
\hline \multirow[t]{5}{*}{22} & Liliaceae & $\begin{array}{l}\text { Bawang } \\
\text { merah }\end{array}$ & Allium cepa Var. & Umbi & $\begin{array}{l}\text { Dipotong dan } \\
\text { diremas/ } \\
\text { Dibalurkan }\end{array}$ & Masuk angin, demam \\
\hline & & $\begin{array}{l}\text { Bawang } \\
\text { putih }\end{array}$ & Allium sativum $\mathrm{L}$. & Umbi & $\begin{array}{l}\text { Dipotong/ } \\
\text { Dioleskan }\end{array}$ & Bisul, jerawat \\
\hline & & $\begin{array}{l}\text { Lidah } \\
\text { buaya }\end{array}$ & Aloe vera $\mathrm{L}$. Burm. F. & Daun & $\begin{array}{l}\text { Dipotong/ } \\
\text { Dioleskan }\end{array}$ & Luka bakar, jerawat \\
\hline & & Andong & $\begin{array}{l}\text { Cordyline terminalis } \\
\text { L. }\end{array}$ & Daun & $\begin{array}{l}\text { Ditumbuk/ } \\
\text { Ditempelkan }\end{array}$ & Luka berdarah, memar \\
\hline & & & & Daun & $\begin{array}{l}\text { Direbus/ } \\
\text { Diminum }\end{array}$ & Diabetes, TBC \\
\hline 23 & Lygodiaceae & Beribu & $\begin{array}{l}\text { Lygodium } \\
\text { microphyllum }\end{array}$ & Daun & $\begin{array}{l}\text { Ditumbuk/ } \\
\text { Ditempelkan }\end{array}$ & Obat luka dari sengatan binatang \\
\hline \multirow[t]{2}{*}{24} & Malvaceae & $\begin{array}{l}\text { Bunga } \\
\text { Lampu }\end{array}$ & $\begin{array}{l}\text { Hibiscus rosa-sinensis } \\
\text { L. }\end{array}$ & $\begin{array}{l}\text { Akar dan } \\
\text { bunga }\end{array}$ & $\begin{array}{l}\text { Direbus/ } \\
\text { Diminum }\end{array}$ & $\begin{array}{l}\text { Demam, mengeluarkan racun dari } \\
\text { dalam tubuh }\end{array}$ \\
\hline & & Rosella & Hibiscus sabdariffa $\mathrm{L}$. & Buah & $\begin{array}{l}\text { Direbus/ } \\
\text { Diminum }\end{array}$ & $\begin{array}{l}\text { Nyeri haid, mual dan muntah,, suara } \\
\text { parau darah tinggi }\end{array}$ \\
\hline 25 & Melastomaceae & Cengkodok & $\begin{array}{l}\text { Melastoma } \\
\text { malabathricum }\end{array}$ & Daun & $\begin{array}{l}\text { Direbus/ } \\
\text { Diminum }\end{array}$ & Diare \\
\hline 26 & Menispermaceae & Brotowali & $\begin{array}{l}\text { Tinospora crispa }(\mathrm{L} .) \\
\text { Hook F. \& T }\end{array}$ & Batang & $\begin{array}{l}\text { Direbus/ } \\
\text { Diminum }\end{array}$ & $\begin{array}{l}\text { Demam, obat dalam, penambah nafsu } \\
\text { makan, kencing manis }\end{array}$ \\
\hline
\end{tabular}


Protobiont (2018) Vol. 7 (3) : 36 -46

\begin{tabular}{|c|c|c|c|c|c|c|}
\hline No. & Famili & $\begin{array}{c}\text { Nama } \\
\text { Daerah }\end{array}$ & Nama Spesies & $\begin{array}{c}\text { Bagian } \\
\text { Tumbuhan }\end{array}$ & $\begin{array}{c}\text { Cara } \\
\text { Pengolahan/ } \\
\text { Penggunaan }\end{array}$ & Kegunaan \\
\hline & & Cincau & Cyclea laxiflora & Daun & $\begin{array}{l}\text { Diremas dan } \\
\text { dipotong/ } \\
\text { Dimakan }\end{array}$ & $\begin{array}{l}\text { Radang lambung, penurun panas, } \\
\text { keracunan makanan }\end{array}$ \\
\hline 27 & Mimosaceae & Putri malu & Mimosa pudica $\mathrm{L}$. & Daun & $\begin{array}{l}\text { Direbus/ } \\
\text { Diminum }\end{array}$ & Batuk, susah tidur \\
\hline \multirow[t]{2}{*}{28} & Moraceae & Sukun & $\begin{array}{l}\text { Artocarpus altilis } \\
\text { (Park.) Fsb. }\end{array}$ & Daun & $\begin{array}{l}\text { Direbus/ } \\
\text { Diminum }\end{array}$ & Obat dalam, nifas (mencairkan darah) \\
\hline & & Keluwih & $\begin{array}{l}\text { Artocarpus camansi } \\
\text { (Park.) Fsb. }\end{array}$ & Daun & $\begin{array}{l}\text { Direbus/ } \\
\text { Diminum }\end{array}$ & Disentri \\
\hline \multirow[t]{2}{*}{29} & Myrtaceae & Jambu batu & Psidium guajava $\mathrm{L}$. & Daun & $\begin{array}{l}\text { Direbus/ } \\
\text { Diminum }\end{array}$ & Sakit perut, diare \\
\hline & & Salam & $\begin{array}{l}\text { Syzigium polyanthum } \\
\text { Wigh. Walp }\end{array}$ & Daun & $\begin{array}{l}\text { Direbus/ } \\
\text { Diminum }\end{array}$ & Sakit maag, darah tinggi \\
\hline 30 & Oleaceae & $\begin{array}{l}\text { Bunga } \\
\text { Melati }\end{array}$ & $\begin{array}{l}\text { Jasminum sambac }(\mathrm{L} .) \\
\text { Aiton }\end{array}$ & $\begin{array}{l}\text { Bunga dan } \\
\text { daun }\end{array}$ & $\begin{array}{l}\text { Direbus/ } \\
\text { Diminum }\end{array}$ & $\begin{array}{l}\text { Demam, sakit kepala, sesak } \\
\text { nafas/asma }\end{array}$ \\
\hline 31 & Pandanaceae & Pandan & $\begin{array}{l}\text { Pandanus } \\
\text { amarylifolius Roxb. }\end{array}$ & Daun & $\begin{array}{l}\text { Direbus/ } \\
\text { Diminum }\end{array}$ & Pegal linu, penambah nafsu makan \\
\hline 32 & Papilionaceae & Dadap & $\begin{array}{l}\text { Erythrina subumbrans } \\
\text { (Hassk.) Merr. }\end{array}$ & Daun & $\begin{array}{l}\text { Direbus/ } \\
\text { Diminum }\end{array}$ & Nifas, radang perut, demam \\
\hline \multirow[t]{4}{*}{33} & Piperaceae & Sahang & Piper nigrum $\mathrm{L}$. & Buah & $\begin{array}{l}\text { Dipotong/ } \\
\text { Dimakan }\end{array}$ & Perut kembung \\
\hline & & Sirih & Piper betle $\mathrm{L}$. & Daun & $\begin{array}{c}\text { Direbus/ } \\
\text { Dibasuhkan }\end{array}$ & Obat mata, antiseptic, keputihan \\
\hline & & Sirih merah & $\begin{array}{l}\text { Piper crocatum Ruiz } \\
\text { et Paw }\end{array}$ & Daun & $\begin{array}{c}\text { Digulung/ } \\
\text { Ditempelkan }\end{array}$ & Mimisan \\
\hline & & & & & $\begin{array}{l}\text { Direbus/ } \\
\text { Diminum }\end{array}$ & $\begin{array}{l}\text { Sakit mata, obat kanker, obat dalam, } \\
\text { nifas }\end{array}$ \\
\hline \multirow[t]{4}{*}{34} & Poacea & Lalang & Imperata cylindrica $\mathrm{L}$. & Akar & $\begin{array}{l}\text { Ditumbuk/ } \\
\text { Diminum }\end{array}$ & Panas dalam \\
\hline & & Serai & $\begin{array}{l}\text { Cymbopogon citratus } \\
\text { (L.) Rendle }\end{array}$ & Batang & $\begin{array}{l}\text { Ditumbuk/ } \\
\text { Dikumur }\end{array}$ & Sakit gigi \\
\hline & & & & Batang & $\begin{array}{l}\text { Direbus/ } \\
\text { Mandi }\end{array}$ & Gatal-gatal, bau badan \\
\hline & & Serai wangi & $\begin{array}{l}\text { Cymbopogonnardus } \\
\text { (L.) Rendle }\end{array}$ & Batang & $\begin{array}{l}\text { Direbus/ } \\
\text { Mandi }\end{array}$ & Gatal-gatal, bau badan \\
\hline \multirow[t]{2}{*}{35} & Polypodiaceae & Sisik Naga & $\begin{array}{l}\text { Drymoglossum } \\
\text { piloselloides (L.) } \\
\text { Presl. }\end{array}$ & Daun & $\begin{array}{c}\text { Ditumbuk/ } \\
\text { Ditempelkan }\end{array}$ & Bisul \\
\hline & & & & Daun & $\begin{array}{l}\text { Direbus/ } \\
\text { Diminum }\end{array}$ & Obat dalam, muntah darah \\
\hline 36 & Portulacaceae & Ginseng & Talinum paniculatum & Umbi & $\begin{array}{l}\text { Direbus/ } \\
\text { Diminum }\end{array}$ & Menjaga daya tahan tubuh \\
\hline \multirow[t]{5}{*}{37} & Rubiaceae & Cengkudu & Morinda citrifolia $\mathrm{L}$. & Buah & $\begin{array}{l}\text { Diperas/ } \\
\text { Diminum }\end{array}$ & Tekanan darah tinggi \\
\hline & & Kacapiring & $\begin{array}{l}\text { Gardenia augusta } \\
\text { Merr. }\end{array}$ & Daun & $\begin{array}{l}\text { Direbus/ } \\
\text { Diminum }\end{array}$ & $\begin{array}{l}\text { Sakit perut, sakit pinggang, darah } \\
\text { tinggi }\end{array}$ \\
\hline & & Kopi & Coffea arabica $\mathrm{L}$. & Akar & $\begin{array}{l}\text { Ditumbuk/ } \\
\text { Diminum }\end{array}$ & Nyeri sendi \\
\hline & & Asoka & Ixora coccinea $\mathrm{L}$. & $\begin{array}{c}\text { Kulit } \\
\text { batang }\end{array}$ & $\begin{array}{l}\text { Direbus/ } \\
\text { Diminum }\end{array}$ & $\begin{array}{l}\text { Menghantikan darah mestruasi yang } \\
\text { berlebih }\end{array}$ \\
\hline & & $\begin{array}{l}\text { Rumput } \\
\text { jerman }\end{array}$ & Spermacocea latifolia & Daun & $\begin{array}{c}\text { Ditumbuk/ } \\
\text { Ditempelkan }\end{array}$ & $\begin{array}{l}\text { Menghentikan pendarahan pada luka } \\
\text { berdarah }\end{array}$ \\
\hline
\end{tabular}


Protobiont (2018) Vol. 7 (3) : $36-46$

\begin{tabular}{|c|c|c|c|c|c|c|}
\hline No. & Famili & $\begin{array}{l}\text { Nama } \\
\text { Daerah }\end{array}$ & Nama Spesies & $\begin{array}{l}\text { Bagian } \\
\text { Tumbuhan }\end{array}$ & $\begin{array}{c}\text { Cara } \\
\text { Pengolahan/ } \\
\text { Penggunaan } \\
\end{array}$ & Kegunaan \\
\hline \multirow[t]{2}{*}{38} & Rutaceae & Jeruk nipis & $\begin{array}{l}\text { Citrus aurantifolia } \\
\text { (Christm.) Swingle, } \\
\text { orth. }\end{array}$ & Buah & $\begin{array}{l}\text { Diperas/ } \\
\text { Diminum }\end{array}$ & $\begin{array}{l}\text { Batuk, sakit tenggorokan, } \\
\text { memelihara daya tahan tubuh }\end{array}$ \\
\hline & & $\begin{array}{l}\text { Jeruk } \\
\text { sambal }\end{array}$ & Citrus microcarpa & Buah & $\begin{array}{l}\text { Diperas/ } \\
\text { Diminum }\end{array}$ & Sariawan, batuk \\
\hline 39 & Sapindaceae & Rambutan & $\begin{array}{l}\text { Nephelium lappaceum } \\
\text { L. }\end{array}$ & Kulit kayu & $\begin{array}{l}\text { Direbus/ } \\
\text { Diminum }\end{array}$ & Demam, sariawan \\
\hline 40 & Sapotaceae & Sawo & $\begin{array}{l}\text { Manilkara zapote }(\mathrm{L} .) \\
\text { P. Royen }\end{array}$ & Buah & $\begin{array}{l}\text { Direbus/ } \\
\text { Diminum }\end{array}$ & Diare, insomnia \\
\hline 41 & Solanaceae & Leletup & Physalis angulata $\mathrm{L}$. & $\begin{array}{l}\text { Seluruh } \\
\text { bagian } \\
\text { tumbuhan }\end{array}$ & $\begin{array}{l}\text { Direbus/ } \\
\text { Diminum }\end{array}$ & Diabetes, sakit paru-paru \\
\hline \multirow[t]{3}{*}{42} & Verbenaceae & $\begin{array}{l}\text { Daun } \\
\text { Bebuas }\end{array}$ & Premna serratifoia L. & Daun & $\begin{array}{l}\text { Direbus/ } \\
\text { Dimakan }\end{array}$ & Menghilangkan bau badan \\
\hline & & Jarong & $\begin{array}{l}\text { Stachytarpheta } \\
\text { jamaicensis }\end{array}$ & Daun & $\begin{array}{l}\text { Ditumbuk/ } \\
\text { Ditempelkan }\end{array}$ & Koreng, penutup luka \\
\hline & & & & Daun & $\begin{array}{l}\text { Direbus/ } \\
\text { Dimakan }\end{array}$ & Pembersih darah, peluruh kencing \\
\hline \multirow[t]{13}{*}{43} & Zingeberaceae & Banglai & $\begin{array}{l}\text { Zingiber purpureum } \\
\text { Roxb. }\end{array}$ & Rimpang & $\begin{array}{c}\text { Diparut, diperas, } \\
\text { direbus/ } \\
\text { Diminum }\end{array}$ & $\begin{array}{l}\text { Sakit perut, cacingan, menjaga daya } \\
\text { tahan tubuh }\end{array}$ \\
\hline & & Cekur & $\begin{array}{l}\text { Kaempferia galanga } \\
\mathrm{L} .\end{array}$ & Rimpang & $\begin{array}{c}\text { Diparut, diperas, } \\
\text { direbus/ } \\
\text { Diminum }\end{array}$ & Sakit perut, nifas \\
\hline & & & & Rimpang & $\begin{array}{l}\text { Ditumbuk/ } \\
\text { Dibalurkan }\end{array}$ & Antiradang \\
\hline & & Kunyit & $\begin{array}{l}\text { Curcuma domestica } \\
\text { Val. }\end{array}$ & Rimpang & $\begin{array}{c}\text { Diparut, diperas, } \\
\text { direbus/ } \\
\text { Diminum }\end{array}$ & Nifas, melancarkan datang bulan \\
\hline & & Intamu & Curcuma heyneana & Rimpang & $\begin{array}{c}\text { Ditumbuk/ } \\
\text { Ditempelkan }\end{array}$ & Panu \\
\hline & & Lengkuas & Alpinia galanga $\mathrm{L}$. & Rimpang & $\begin{array}{l}\text { Ditumbuk/ } \\
\text { Dibalurkan }\end{array}$ & Radang sendi \\
\hline & & Liak & $\begin{array}{l}\text { Zingiber officinale } \\
\text { Rosc. }\end{array}$ & Rimpang & $\begin{array}{c}\text { Diparut, diperas, } \\
\text { direbus/ } \\
\text { Diminum }\end{array}$ & $\begin{array}{l}\text { Radang perut, mual-mual, penambah } \\
\text { stamina, nifas }\end{array}$ \\
\hline & & Liak merah & $\begin{array}{l}\text { Zingiber officinale } \\
\text { Var. Rubrum Th. }\end{array}$ & Rimpang & $\begin{array}{c}\text { Diparut, diperas, } \\
\text { direbus/ } \\
\text { Diminum }\end{array}$ & $\begin{array}{l}\text { Nifas, pereda kejang, mual-mual } \\
\text { Penambah stamina, masuk angin }\end{array}$ \\
\hline & & & & Rimpang & $\begin{array}{l}\text { Ditumbuk/ } \\
\text { Dibalurkan }\end{array}$ & Antiradang \\
\hline & & Ntemu & $\begin{array}{l}\text { Curcuma xanthorriza } \\
\text { Roxb. }\end{array}$ & Rimpang & $\begin{array}{l}\text { Ditumbuk/ } \\
\text { Dibalurkan }\end{array}$ & Cacar air \\
\hline & & & & Rimpang & $\begin{array}{c}\text { Diparut, diperas, } \\
\text { direbus/ } \\
\text { Diminum }\end{array}$ & $\begin{array}{l}\text { Gangguan hati, hepatitis, kolesterol, } \\
\text { penambah nafsu makan }\end{array}$ \\
\hline & & Combrang & $\begin{array}{l}\text { Etlingera elatior } \\
\text { (Jack) R. M. Sm. }\end{array}$ & Bunga & $\begin{array}{l}\text { Direbus/ } \\
\text { Dimakan }\end{array}$ & $\begin{array}{l}\text { Memperbanyak ASI, penurun panas/ } \\
\text { demam }\end{array}$ \\
\hline & & & & Bunga & $\begin{array}{c}\text { Dilayukan/ } \\
\text { Ditempelkan }\end{array}$ & Sakit gigi \\
\hline & & & & No. & Nama F & $\begin{array}{c}\text { Persentase } \\
(\%)\end{array}$ \\
\hline
\end{tabular}


Protobiont (2018) Vol. 7 (3) : $36-46$

\begin{tabular}{|c|c|c|c|}
\hline 1 & $\begin{array}{l}\text { Zingiberaceae, } \\
\text { Euphorbiaceae }\end{array}$ & 9 & $9,7^{*}$ \\
\hline 2 & Asteraceae & 8 & 8,6 \\
\hline 3 & Rubiaceae & 5 & 5,4 \\
\hline 4 & Liliaceae, Fabaceae & 4 & $4,3^{*}$ \\
\hline 5 & $\begin{array}{l}\text { Acanthaceae, Piperaceae, } \\
\text { Poaceae }\end{array}$ & 3 & $3,2^{*}$ \\
\hline 6 & $\begin{array}{l}\text { Apiaceae, } \\
\text { Apocynaceae, } \\
\text { Lamiaceae, } \\
\text { Manispermaceae, Moraceae, } \\
\text { Myrtaceae, } \\
\text { Verbenaceae }\end{array}$ & 2 & $2,1^{*}$ \\
\hline 7 & $\begin{array}{l}\text { Amaranthaceae, } \\
\text { Annonaceae, } \\
\text { Araceae, Basellaceae, } \\
\text { Bromeliaceae, Caricaceae, } \\
\text { Convolvulaceae, } \\
\text { Crasulaceae, Cyperaceae, } \\
\text { Dilleniaceae,Iridaceae, } \\
\text { Lauraceae, Lygodiaceae, } \\
\text { Melastomaceae, } \\
\text { Mimosaceae, Oleaceae, } \\
\text { Pandanaceae, Papilionaceae, } \\
\text { Polypodiaceae, } \\
\text { Portulacaceae, Sapindaceae, } \\
\text { Sapotaceae, Solanaceae }\end{array}$ & 1 & $1,1^{*}$ \\
\hline
\end{tabular}

Persentase jenis-jenis tumbuhan yang berpotensi sebagai obat yang ditemukan di Desa Durian sebatang dikelompokan ke dalam 43 famili, dengan persentase jenis terbesar adalah Zingiberaceae dan Euphorbiaceae 9,7\% dan persentase jenis terkecil adalah Moraceae sampai Solanaceae 1\%, (Tabel 2). Persentase bagian tumbuhan yang dimanfaatkan sebgai obat oleh Suku Melayu Desa Durian Sebatang adalah 13 Bagian yaitu daun, batang,kulit kayu, getah, lendir, akar, rimpang, umbi, bunga, buah, biji, air buah, dan seluruh bagian tumbuhan. Persentase tertinggi bagian tumbuhan obat yaitu daun $48 \%$, sedangkan persentase terendah yaitu lendir, biji, dan air buah 1\% (Gambar 2).

Persentase cara pengolahan tumbuhan obat oleh masyarakat Desa Durian Sebatang ada 8 yaitu rebus, tumbuk, potong, parut, remas, peras, gulung, dan layukan. Persentase tertinggi cara pengolahan tumbuhan obat adalah rebus $48 \%$, sedangkan persentase terendah adalah gulung, dan layukan $1 \%$ (Gambar 3).

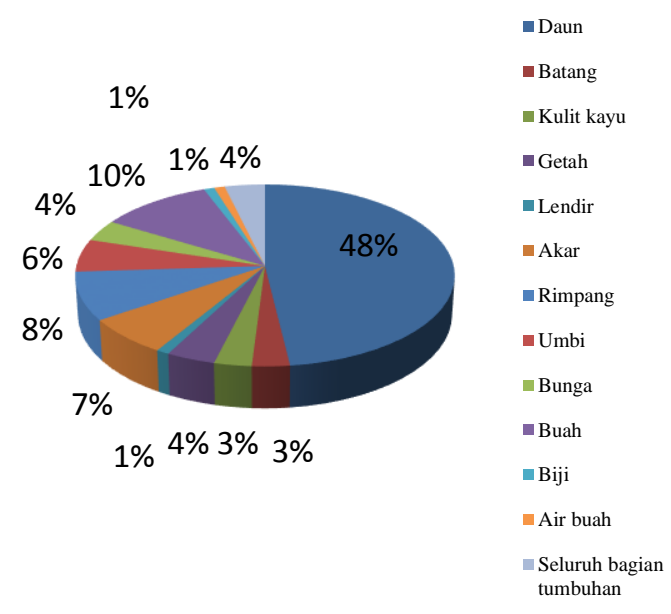

Gambar 2. Bagian Tumbuhan Obat

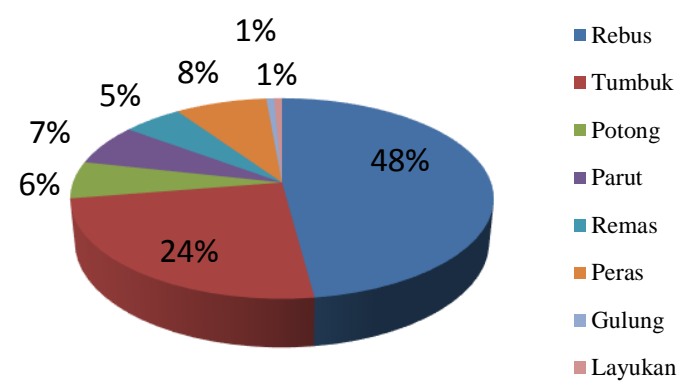

Gambar 3. Cara Pengolahan Tumbuhan Obat

Persentase cara penggunaan tumbuhan obat oleh masyarakat Desa Durian Sebatang ada 9 yaitu minum, tempel, makan, oles, balur, basuh, kumur, keramas dan mandi. Persentase tertinggi cara penggunaan tumbuhan obat adalah minum 53\%, sedangkan persentase cara penggunaan tumbuhan obat terendah adalah kumur dan keramas $1 \%$ (Gambar 4). 
Protobiont (2018) Vol. 7 (3) : $36-46$

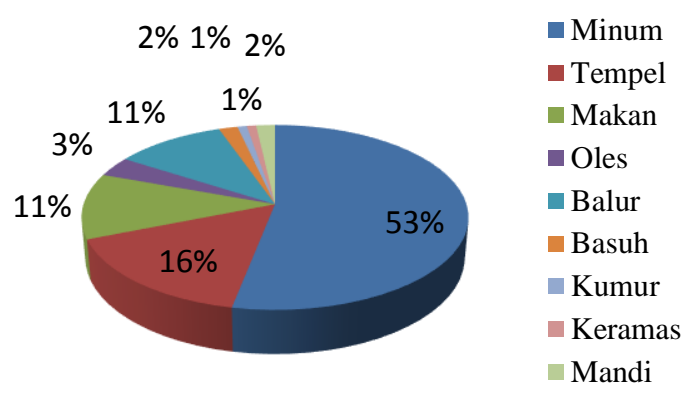

Gambar 4. Cara Penggunaan Tumbuhan Obat

Persentase tumbuhan obat yang dimanfaatkan oleh Suku Malayu Desa Durian Sebatang diambil dari beberapa tempat yaitu di pekarangan rumah, hutan, sawah dan kebun. Sebagian besar tumbuhan obat diperoleh di hutan (Gambar 5).

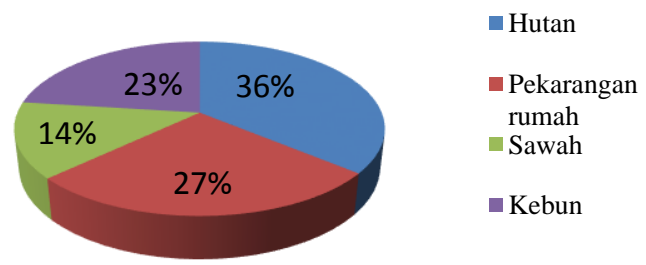

Gambar 5. Tempat Tumbuhan Obat

\section{Pembahasan}

\section{Famili dan Jenis Tumbuhan Obat}

Berdasarkan jenis tumbuhan obat yang digunakan oleh masyarakat Suku Melayu di Desa Durian Sebatang terdapat 43 famili dari 93 spesies (Tabel 1). Hasil penelitian ini menemukan spesies yang lebih banyak dibandingkan dengan hasil penelitian Aminah (2013) yaitu terdapat 78 spesies tumbuhan obat di Desa Sejahtera Kecamatan Sukadana Kabupaten Kayong Utara. Keanekaragaman famili dan jenis tumbuhan yang berpotensi sebagai tumbuhan obat di Desa Durian Sebatang menggambarkan tingginya variasi jenis tumbuhan yang dapat dijadikan bahan obat tradisional. Nilai persentase jenis tumbuhan obat berdasarkan famili adalah Zingiberaceae dan Euphorbiaceae yaitu 9,7\%, Asteraceae 8,6\%, Rubiaceae 5,4\%. Tingginya FamiliZingiberaceae dan Euphorbiaceae tersebut dikarenakan jenis tumbuhan dari kedua famili tersebut dipercaya dapat digunakan sebagai ramuan obat yang dapat menyembuhkan berbagai penyakit.

Famili Zingiberaceae banyak ditanam oleh masyarakat Suku Melayu Desa Durian Sebatang di pekarangan rumah atau di kebun, hal ini dikarenakan tingginya kebutuhan masyarakat terhadap tumbuhan famili Zingiberaceae untuk digunakan sebagai bahan obat tradisional dan sebagai bahan bumbu dapur. Selain itu, kondisi lingkungan juga mendukung pertumbuhan tumbuhan famili Zingiberaceae sehingga dapat tumbuh dan berkembang dengan baik. Pernyataan ini didukung oleh hasil penelitian Rukmana (2004) yang menyatakan bahwa Famili Zingiberaceae paling banyak ditemukan di berbagai lingkungan pedesaan. Selain itu hasil penelitian Jaini (1994) di Waringin Timur

Kalimantan Tengah menunjukan bahwa jenis tumbuhan yang berkhasiat sebagai obat paling banyak ditemukan adalah famili Zingiberaceae. Jenis-jenis tumbuhan dari famili Zingiberaceae yang ditemukan di Desa Durian Sebatang yaitu banglai (Z. purpureumRoxb. ), cekur (Kaempferia galanga L.), kunyit (Curcuma domestica Val.), intamu (Curcuma heyneana), lengkuas (Alpinia galanga L.), liak ( $Z$. officinale), liak merah ( $Z$. officinale Roscoe), ntemu (Curcuma xanthorriza Roxb.), dan combrang (Nicolaria speciosa Horan.).

Famili Euphorbiaceae merupakan tumbuhan herba yang sebagian tidak dibudidayakan dan biasanya terdapat di beberapa tempat yaitu di sekitar pekarangan rumah, kebun, sawah dan hutan. Jenis tumbuhan dari Famili Euphorbiaceae yang dapat dijadikan obat tradisional adalah kribang (Manihot utilissima), jirak (Jatropha curcas L.), jirak hias (Jatropha gossypifolia L.), patah tulang (Cissus quadrangularis L.), meniran (Phylanthus niruri L.), petikan kebo (Euphorbia hirta L.), ekor kucing (Acalypha hispida), keminting (Aleurites moluccana Wild.) dan cangkok manis (Sauropus androgynus (L.) Merr.).

\section{Pemanfaatan Bagian Tumbuhan Obat}

Bagian tumbuhan yang paling banyak dimanfaatkan oleh masyarakat Suku Melayu Desa Durian Sebatang sebagai obat yaitu daun $48,0 \%$, buah $10 \%$, dan rimpang $8 \%$. Tingginya jumlah penggunaan daun oleh masayarakat Suku Melayu Desa Durian Sebatang dikarenakan penggunaan daun sebagai bahan dasar ramuan obat secara tradisional ini pengolahannya lebih mudah, daun bisa langsung diolah dan bisa juga dikeringkan agar tahan lama. Selain itu Zuhud dan Haryanto (1994) mengungkapkan bahwa daun mempunyai khasiat yang lebih baik dibandingkan bagian-bagian tumbuhan lainnya, penggunaan daun sebagai obat juga tidak merusak organ tumbuhan lain karena bagian daun mudah tumbuh kembali dan bisa dimanfaatkan secara berkelanjutan sampai tumbuhan tersebut tua dan mati. 


\section{Protobiont (2018) Vol. 7 (3) : $36-46$}

Penelitian Ernawati (2009) juga menyatakan bagian tumbuhan yang paling banyak digunakan sebagai obat adalah daun. Penggunaan bagian tumbuhan oleh masyarakat Suku Melayu Desa Durian Sebatang sebagai obat untuk setiap jenis tumbuhan tidak selalu sama, tetapi tergantung dari jenis penyakit yang akan disembuhkan dan biasanya bagian tumbuhan yang dipercaya memiliki rasa dan aroma tertentu yang dijadikan bahan obat tradisional. Misalnya daun bebuas (Premma cordiflora) untuk menghilangkan bau badan, gelinggang (Cassia alata) untuk mengobati kurap dan patah kemudi (Gynura segetum (L.) Merr.) untuk patah tulang dan obat dalam.

Tumbuhan obat yang bagian buahnya digunakan sebagai obat seperti sawo muda (Manilkara zapote (L.) P. Royen) dipercaya dapat menyembuhkan diare dan insomnia. Tumbuhan obat yang bagian getahnya digunakan sebagai obat yaitu jirak (Jatropha curcas L.) untuk mengobati sariawan. Tumbuhan obat yang bagian rimpangnya digunakan sebagai obat seperti jeringau (Acorus calamus L.) untuk mengobati sakit perut. Tumbuhan obat yang bagian akarnya digunakan sebagai obat seperti akar lalang (Imperata cylindrica L.) untuk panas dalam. Tumbuhan obat yang bagian kulit batangnya digunakan sebagai obat seperti bunga jarum (Ixora Coccinea L.) untuk menghentikan darah menstruasi yang berlebih. Tumbuhan obat yang bagian airnya digunakan sebagai obat seperti kelapa (Cocos nucifera) untuk mengobati cacar air dan keracunan. Tumbuhan obat yang bagian umbinya digunakan sebagai obat seperti bawang mekah (Eleutherine americana) untuk mengobati darah tinggi dan penyakit dalam. Tumbuhan obat yang bagian bunganya digunakan sebagai obat seperti bunga lampu (Hibiscus rosa-sinensis L.) untuk obat demam. Tumbuhan obat yang bagian batangnya digunakan sebagai obat seperti serai (Cymbopogon citratus (L.) Rendle) untuk mengobati sakit gigi dan gatal-gatal. Tumbuhan obat yang bagian bijinya digunakan sebagai obat seperti keminting (Aluerites moluccana (L.) Wild.) sebagai obat sakit gigi.

\section{Cara Pengolahan dan Penggunaan Tumbuhan Obat}

Cara pengolahan dan penggunaan tumbuhan obat oleh masyarakat Suku Melayu di Desa Durian Sebatang masih sangat sederhana. Berdasarkan hasil penelitian persentase cara pengolahan tumbuhan sebagai obat oleh masyarakat Desa Durian Sebatang yaitu direbus (48\%), ditumbuk (24\%) dan diparut (7\%). Sedangkan persentase cara penggunaan tumbuhan sebagai obat oleh masyarakat Desa Durian Sebatang yaitu diminum (53\%), ditempel (16\%), dan dimakan (11\%). Cara pengolahan tumbuhan obat yang dilakukan oleh masyarakat Suku Melayu Desa Durian Sebatang tergantung pada cara penyembuhan penyakit dan jenis tumbuhan yang digunakan. Berdasarkan jenis penyakit yang akan disembuhkan pengobatan yang dilakukan oleh masyarakat Suku Melayu Desa Durian Sebatang ada 2 macam yaitu pengobatan luar dan pengobatan dalam.

Cara pengobatan luar bervariasi berdasarkan jenis penyakitnya. Umumnya jenis pengobatan luar menggunakan tumbuhan tunggal. Sebagian besar cara pengolahan tumbuhannya secara sederhana dengan cara ditumbuk kemudian ditempelkan pada bagian yang sakit. Sedangkan untuk pengobatan dalam, pengolahan tumbuhan obat umumnya dilakukan dengan cara direbus kemudian air rebusannya diminum. Cara pengolahan dan penggunaan tumbuhan obat oleh masyarakat Suku Melayu Desa Durian Sebatang ini tergantung dari jenis tumbuhan yang digunakan dan jenis penyakit yang di sembuhkan.

Masyarakat Desa Durian Sebatang percaya bahwa masing-masing penyakit dapat disembuhkan oleh tumbuhan yang berbeda-beda, namun ada juga tumbuhan yang dapat mengobati jenis penyakit lebih dari satu, yaitu sambiloto (Andrographis paniculata (Burm. F.) Wall.) untuk mengobati kencing batu dan obat dalam, binahong (Anredera cordifolia (Ten.) Steenis.) untuk mengobati diabetes, asam urat dan melancarkan haid, asam jawa (Tamarindus indica L.) untuk mengobati angin duduk, batuk dan demam.

\section{Tempat Pengambilan Tumbuhan Obat}

Tempat pengambilan tumbuhan obat oleh masyarakat Suku Melayu Desa Durian Sebatang yaitu dari hutan (36\%), pekarangan rumah $(27 \%)$, dan kebun (23\%). Tingginya persentase pengambilan tumbuhan obat di hutan disebabkan oleh keanekaragaman jenis tumbuhan yang berkhasiat obat sangat melimpah. Misalnya tumbuhan pelaik (Alstonia scholaris) yang berfungsi sebagai obat sakit gigi dan obat koreng, dan tumbuhan simpur (Dillenia suffriticosa Griff ex Hook) yang berfungsi sebagai obat untuk melancarkan ASI, meriang dan pegalinu. Pengambilan tumbuhan obat di hutan tentunya sangat tidak efektif karena ketika obat tersebut akan digunakan masyarakat harus mencarinya terlebih dahulu ke hutan, oleh karena itu sebagian masyarakat Desa Durian Sebatang berinisiatif untuk mengawetkan tumbuhan obat yang didapat dari hutan dengan cara mengeringkannya. Selain itu, masyarakat Desa Durian Sebatang juga menanam 


\section{Protobiont (2018) Vol. 7 (3) : $36-46$}

kembali tumbuhan yang didapat dari hutan pada pekarangan rumahnya. Tumbuhan obat yang dijumpai di pekarangan rumah adalah sosor bebek (Kalanchoe pinnata) yang berbungsi sebagai obat penurun panas dan obat luka, meniran (Phyllanthus niruri L.) untuk mengobati demam dan peluruh air seni, dan jambu batu (Psidium guajava L.) untuk mengobati diare.

Tempat pengambilan tumbuhan obat selanjutnya adalah kebun. Keberadaan tumbuhan obat di kebun sangat sedikit hal ini dikarenakan kebun hanya dijadikan sebagai tempat menanam sayuran atau buah-buahan. Tumbuhan obat yang dapat ditemui di kebun yaitu daun bebuas (Premna serratifolia L.), cengkodok (Melastoma malabathricum), daun beribu (Lygodium microphyllum), putri malu (Mimosa pudica L.), alang-alang (Imperata cylindrica L.), rumput jerman (Spermacocea latifolia), keribang (Manihot utilissima L.). dankerisan (Scleria bancana). Masyarakat Suku Melayu Desa Durian Sebatang hanya memanfaatkan tumbuhan untuk memenuhi kebutuhan sehari-hari, baik untuk bahan obat tradisional, bumbu dapur dan bahan pangan lainnya hal ini dilakukan secara turun-temurun.

\section{DAFTAR PUSTAKA}

Aminah, S, 2016, Pemanfaatan Tanaman Obat oleh Battra dalam Pengobatan Tradisional di Desa Sejahtera Kecamatan Sukadana Kabupaten Kayong Utara, Jurnal Hutan Lestari, Vol.1 No.3 hal:301-315

Badan Pusat Statistik Kabupaten Kayong Utara (BPS KKU), 2016, Kecamatan Seponti Dalam Angka 2016, diakses 31 Juli 2017, <http://kayongutarakab.bps.go.id >

Badan POM RI, 2008, Taksonomi Koleksi Tanaman Obat, Kebun Tanaman Obat Citeureup, Jakarta

Ernawati, E, 2009, Etnobotani Masyarakat SukuMelayu Daratan, Skripsi, Fakultas Kehutanan,IPB
Galeri Tumbuhan, Plantamor, diakses Januari 2018, $<$ http://www.plantamor.com $>$

Harada, K, Mulyati Rahayu, dan Anwar Muzakkir, 2006, Tumbuhan Obat Taman Nasional Gunung Halimun Jawa Barat Indonesia, PALMedia Creative Pro, Bandung

Jaini, 1994, Potensi Tumbuhan Buah-buahan danTumbuhan Obat Pada Kebun Plasma Nutfah diAreal HPH PT Sari Bumi Kusuma SintangKalimantan Barat, Skripsi, FakultasPertanian, Universitas Tanjungpura, Pontianak

Notherfer, B, 1996, Lecturer in German and French Philology, Dept. ofForeign Languages, Millersville State College, Penn

Rukmana, R, 2004, Temu-temuan Apotik Hidup diperkarangan, Penerbit Kanisius, Yogyakarta

Sugiyono, 2014, Metode Penelitian Pendidikan (Pendekatan Kuantitatif, Kualitatif dan $R \& D$, Cetakan ke-20, Alfabeta: Bandung

Suryansyah, G, 2011, Laporan Pelaksanaan Kegiatan Ziarah Akbar dan Tumpng Negeri, Landak

Steenis, V, Hoed, Bloembergen, dan Eyma, 2005, Flora, PT, Pradnya Paramita, Jakarta

The Palnt Observatory, Nature Love You, diakses Januari 2018, <http://www.natureloveyou.sg/>

Zuhud, EAM \& Haryanto, 1994, PelestarianPemanfaatan Keanekaragaman Tumbuhan ObatHutan Tropika Indonesia, Kerjasama JurusanKonservasi Sumber Daya Hutan, Skripsi, FakultasKehutanan IPB dengan Lembaga Alam Tropika,Bogor 